\title{
3. 電子ペーパディスプレイの印刷製造技術
}

キーワードロ電子ペーパ, ディスプレイ, 電気泳動方式, ディジタルサイネージ

\section{1 ま え がき}

印刷技術は，文字や画像などの視覚情報を大量かつ安価 に複製する技術である，一方，印刷技術を材料の加工手段 としてとらえると，「製膜とパターニングを同時に行う技 術」としてとらえることができる，このため，印刷技術は， 従来のフォトリソグラフィにかわる低コストの加工技術と して期待でき，最近注目を集めている1).

電子ディスプレイの製造において，高精細印刷技術はパ ターニングに活用されるが，電気泳動方式の電子ペーパデ イスプレイの場合，表示部材としての前面板 ${ }^{2}$ にはパター ンが存在しないが, 表示材料のマイクロカプセルを単層で 均一に塗工する技術が必要である。

一方, 高解像度が要求され, 現在はガラス基板にフォト リソグラフィで形成されるのが主流であるTFT（Thin Film Transistor：薄膜トランジスタ)アレイを代替する技 術として, 有機トランジスタの製造に印刷技術は使えると 期待されている.

実際，通常の印刷に用いられる印刷インキには，有機顔料 や樹脂が多く含まれており, また, 有機トランジスタや有機 ELディスプレイなどにおいて, 有機デバイスとしての機能 を発現する構成要素は，印刷インキと同様の有機物である. したがって，有機デバイスを印刷技術で作製できないか，と 考えるのは当然であるが, 両者はまったく異なる分野の技術 であり，まだその融合は始まったばかりである．ここでは高 精細印刷技術のディスプレイ分野への適用可能性を議論する ための一助として, 既存の印刷技術について概説するととも に，有機トランジスタへの適用例を紹介する.

またこれらの適用分野として有望視される電子ペーパ関 連の最近のトピックスとして, 大面積化・高精細化・カラ 一化・高速化の動向を紹介する.

†凸版印刷株式会社 メディア事業開発本部

"Electronic Paper Displays and Printing Techniques" by Hidetoshi "Heeday" Danjo (Media Business Development, Toppan Printing Co., Ltd., Tokyo)

\section{2 印刷技術 ${ }^{3)}$ と機能性インキへの対応}

既存の印刷技術は，凸版印刷，凹版印刷，平版印刷，孔 版印刷，と無版印刷の五つに大別される(図1)。これらは 版の形状や求められるインキの特性などがすべて異なる.

それぞれの印刷方式で得られる解像度, 得られる膜厚, そして加工速度を示す (表1). なお，これらはあくまでも 一般論であり, さらなる高精細化の検討が現在も進められ ている.

それぞれの印刷方法には適用可能なインキ粘度の範囲が あり,このためパターニングしたい溶液の粘度に合わせて 適切な方法を選択する必要がある.オフセット，スクリー ンは高粘度, フレキソ, グラビアは中粘度, そしてインク ジェットは低粘度溶液のパターニングに適している (図2).

通常の印刷インキは, 色材, 樹脂, 溶媒, 添加剤の四つ から構成される.このうち, 樹脂は基材上に色材を固定す るだけでなく，インキに適当な流動性を与える機能も有す る. 添加剤はインキの流動性の調整や消泡など印刷適性向 上のために用いられる。

プロセス側からは，何らかの樹脂や添加剤を加える，あ るいは，機能性材料だけで通常のインキ同様に取り扱える

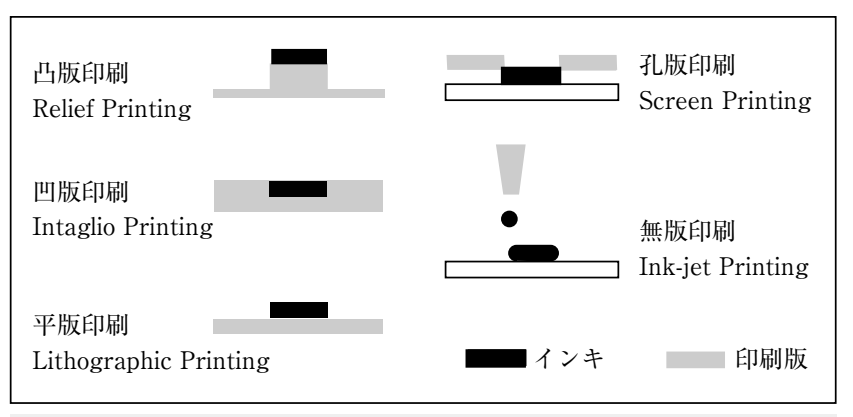

図 1 既存の印刷技術

表 1 印刷方式の特性比較

\begin{tabular}{|l|l|l|l|}
\hline & \multicolumn{1}{|c|}{ Resolution } & \multicolumn{1}{c|}{ Thickness } & \multicolumn{1}{c|}{ Speed } \\
\hline \hline Offset & $>50 \mu \mathrm{m}$ & $>4 \mu \mathrm{m}$ & $90 \sim 300 \mathrm{~m} / \mathrm{min}$ \\
\hline Gravure & $>50 \mu \mathrm{m}$ & $>30 \mu \mathrm{m}$ & $90 \sim 300 \mathrm{~m} / \mathrm{min}$ \\
\hline Flexo & $>75 \mu \mathrm{m}$ & $>10 \mu \mathrm{m}$ & $90 \sim 300 \mathrm{~m} / \mathrm{min}$ \\
\hline Screen & $>100 \mu \mathrm{m}$ & $>125 \mu \mathrm{m}$ & $120 \mathrm{~m} / \mathrm{min}$ \\
\hline
\end{tabular}

(23) 1517 


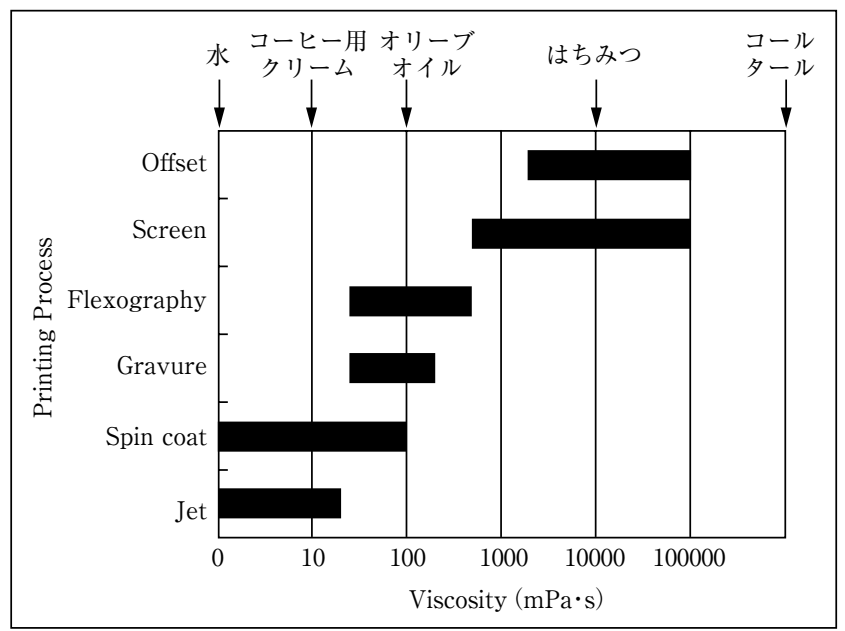

図2 印刷方式と粘度

ことを求める。一方，材料側からは，インキには余計なも のは加えずに，プロセス側でその材料を使いこなすことを 要求することが求められることも想定される。したがって, 現実的には材料, プロセスの双方からの歩み寄りが必要で ある。

\section{3 有機トランジスタ 11}

有機トランジスタは, 半導体材料を含めた構成要素に有 機物を用いたトランジスタであり，比較的低温の溶液プロ セスでの作製が可能である。したがって，プラスチックフ イルムや紙を基板として用いることが可能であり，さらに， 印刷プロセスで加工できれば大量かつ安価に製造できるた め，これまでの真空プロセス主体の半導体製造とは異なる， 新たな技術分野の開拓が期待できる.

現在研究されている有機トランジス夕の多くは電界効果 トランジスタであり, 半導体層, ゲート絶縁膜, ソース・ ドレイン電極, そしてゲート電極の 4 層の積層構造からな る(図3).

ここで，半導体層とゲート絶縁膜は薄くサブミクロンレ ベルにすることが望ましく，ソース・ドレイン電極間の距 離 (チャネル長) は正確に規定されることが必要で，ゲート 電極はチャネル (ソース・ドレイン電極間) から外れてはい けない。

半導体材料はペンタセンに代表されるような低分子有機
半導体とポリチオフェンなどの高分子有機半導体に大別さ れる。 これらのうち，高分子有機半導体は溶媒に可溶であ り，溶液プロセスで製膜・パターニングを行うことができ る. 最近では, 単にトランジス夕を動作させるだけでなく, 電子ペーパを動作させた報告も多い4) 5). 有機半導体より も電子移動度の高い酸化物半導体によるTFTアレイ ${ }^{6)}$ を室 温プロセスで作り，電子ペーパを動作させた例もあり，ソ ース・ドレイン電極を銀ペーストで作るなど，印刷技術の 適用によるコストダウンが指向されている。

これまで発表された「プリンタブル」有機トランジスタは すべてが有機物である例は少なく，トランジス夕を構成す る半導体，電極，ゲート絶縁膜のいずれかについてのみ有 機物を用いたものが多い.「プリンタブル」といっても実際 はスピンコートのようなロールッーロール方式とは相性の 悪いプロセスを用いており，それ以外は真空蒸着やフォト リソグラフィで加工している例が多い.

\section{4 マイクロカプセル型電気泳動方式電子 ペーパ}

電子ペーパの分野で商用化が進んでいる，マイクロカプ セル型電気泳動方式の表示原理を説明する(図4)。直径40 $\mu \mathrm{m}$ 程度の透明なマイクロカプセルの中に, マイナスに带 電した黒い顔料粒子とプラスに带電した白い顔料粒子が透 明なオイル状の分散媒に封じてあり，マイクロカプセルは， 樹脂基材に均一に単層コーティングされている.

樹脂基材には，ITO (インジウムスズ酸化物) の透明電極 面がスパッタリングで形成されており，画素電極との間で 電界を発生させることで，電気泳動現象により带電粒子が 上下移動して描画を行う．白い粒子が上に集まったマイク ロカプセルを上から見ると白く見え，逆の電界が掛かると 黒く見える．グレースケール表示は，パルス幅変調や電圧 変調などによって実現する，表示解像度は，画素電極の細 かさによって決まり，マイクロカプセルの大きさや輪郭に は，基本的には影響されない。

樹脂基材・透明電極・マイクロカプセルの層構成からな る, 表示用のフィルム部材を前面板と呼ぶ. 高解像度の電 子ペーパディスプレイのセルは，前面板を反射型LCD（液 晶ディスプレイ) 用と似たTFTアレイ基板にラミネートし

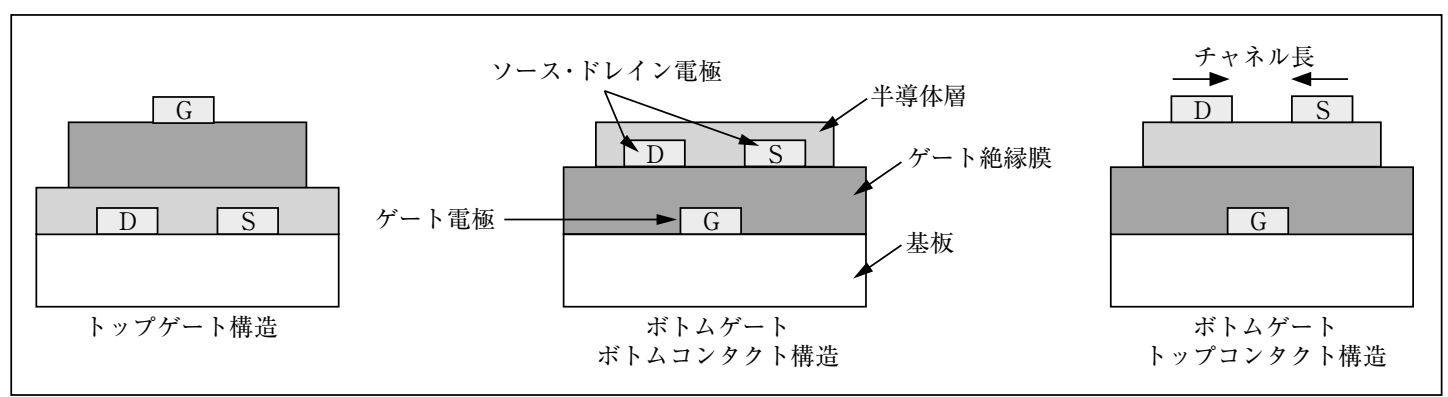

図3 薄膜トランジスタの構造 


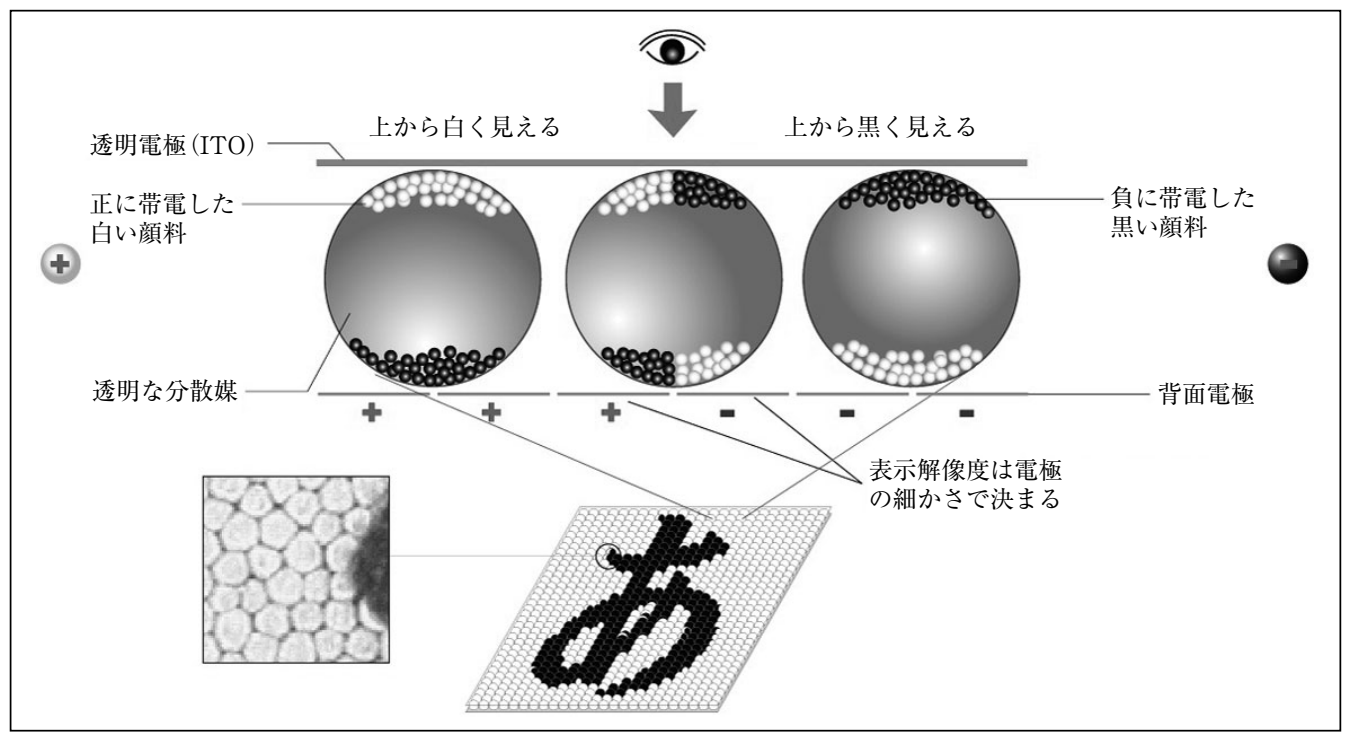

図4 マイクロカプセル型電気泳動方式電子ペーパの表示原理

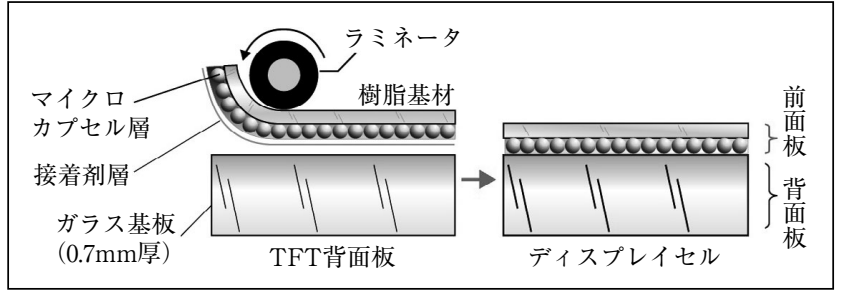

図5 電子ペーパディスプレイのセル化

て製造する(図5). 既存のLCD製造インフラを活用して比 較的低リスクで製造が可能で，低コスト化が期待できる.

\section{5 電子ペーパ関連の最近のトピックス}

電子ペーパの分野で2008年現在, 大きな話題を呼んでい るのが，2007年秋に米国で発売された無線通信型の電子ブ ックリーダ7)である（図6)。表示の仕様は，画面サイズ6イ ンチ, 解像度 $600 \times 800$ 画素, 約 $167 \mathrm{ppi}, 4$ 階調グレースケ ールで，これは2004年に日本で発売された，世界初の電気 泳動方式電子ペーパ搭載の商品8) と大差はない.

異なるのはコンテンツと使い勝手である。書籍, 新聞, 雑誌などが執筆時点で 15 万点, と日本での試みの約 30 倍, 米国の他製品 ${ }^{9)}$ の約3倍の品揃えである. 第三世代携帯電話 網の無線通信 (EVDO) をユーザは無料で使うことができ, 「圈外」でなければ，パソコンなしに，その場で1分以内に 電子的に本を購入できる。これは「紙のような表示」に留ま らず，デリバリーの利便性では, 紙の本を超えていると言 える。

この電子ブックリーダを開発したオンライン書店は，過 去にあらゆる言語で印刷されたすべての本を60秒以内に買 えるようにする，という長期ビジョンを発表している ${ }^{10)}$.

電子書籍以外の分野でも, 電気泳動方式電子ペーパを主 画面に採用したBRICs諸国向け携帯電話 ${ }^{11)}$ (図7)はミリオ

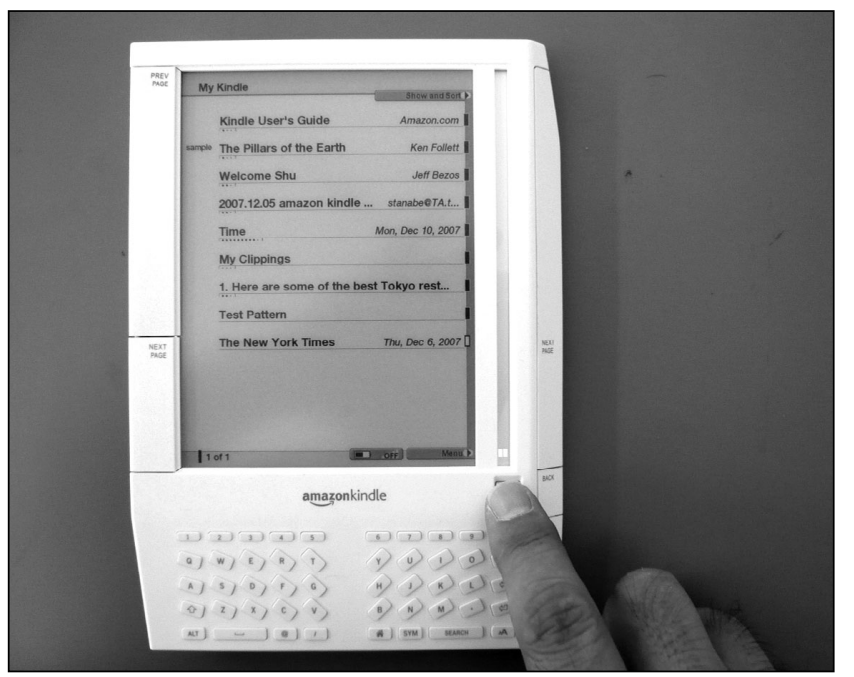

図6＼cjkstart米国の無線通信型電子ブックリーダー

ンセラーとなり，国内でも，電子ペーパを装飾的に使った 機種 ${ }^{12)}$ に続き, 薄型・耐衝撃性能・常時表示といった機能 面からサブディスプレイに採用した ${ }^{13)}$ 二機種目 ${ }^{14)}$ が発表さ れ，電子ペーパも普及期の萌芽を見せ始めている。

\section{1 大面積化}

執筆時点では, 商用化されている電子ペーパでは6イン チが最も量産されているサイズだが，A5サイズに近い 9.7 インチまで発表15)されている。 サンプル出荷されている方 式では，A3サイズ16) まで存在する.

学会の展示では, 2007年のSID (Society for Information Display) で, 韓国のLCDメーカが，14インチを超えるフレ キシブルカラー電子ペーパの試作物や40インチの試作物を 展示した ${ }^{17)}$. 後者は液晶テレビ用のガラス基板TFTアレイ を利用したと考えられる。

また筆者のグループでは, 額縁を $0.5 \mathrm{~mm}$ まで狭くしてタ イル化を可能にした直接駆動方式の電子ペーパディスプレ 


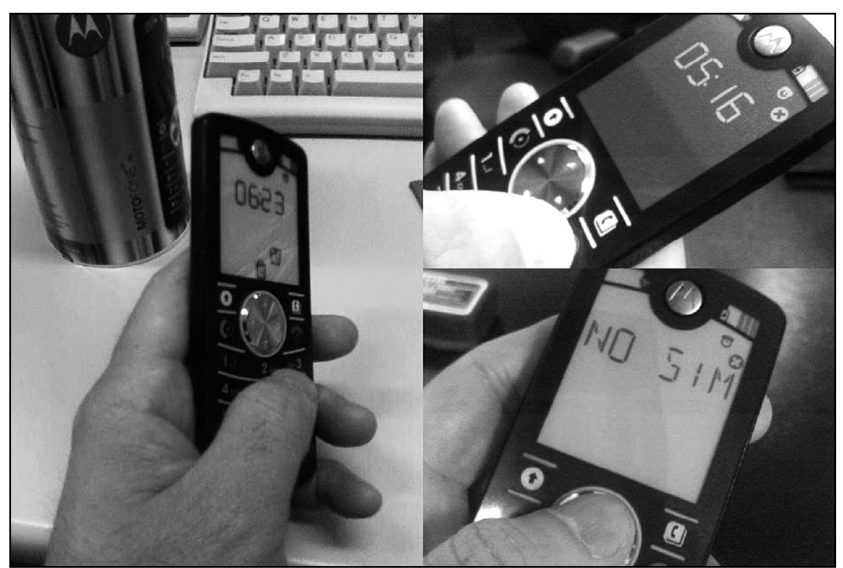

図7電子ペーパを主画面に採用したBRICs諸国向け携帯電話

イを，大型表示用途向けに開発しており，仙台市交通局と 情報・広告配信の共同実証実験を地下鉄仙台駅で実施して いる (図8)。これは縦 $5 \times$ 横4の 20 枚のタイルで 72 インと したもので，冷却ファンから入る鉄粉などにより，LCDや プラズマディスプレイが設置しづらい地下鉄線路脇に設置 している18).

消費電力が，表示部で画面更新時のみ $4 \mathrm{~W}$ ，制御部で $8 \mathrm{~W}$, 小型PCおよび通信部で $9 \mathrm{~W}$ と，合計最大 $21 \mathrm{~W}$ とさいため, 容易に密閉構造して，鉄粉対策を施すことが可能であった． 白黒表示のみで, 1画素が4mm角（解像度は約6ppi）と, 離 れて見ることが前提であるが，可変表示が少ない地下鉄で は, 駅利用者の注目率は $70 \%$ 前後と高く, 情報を 15 秒毎に 切替えて提供することで, 蛍光灯で内側から照らす従来の 固定表示の内照式看板に比べて, 注目率は 20 ポイント以上, と大幅に上昇した ${ }^{19)}$.

\section{2 高精細化}

電気泳動方式の電子ペーパでは, 解像度 $400 \mathrm{ppi}$ 前後の試 作が，シリコンチップ20) やプラスチック基板上 ${ }^{21)}$ で行われ ているが，対角の寸法が1インチや7.1インチと小さかった. 2008年のSIDでは，A4サイズに近い13.4インチ，3,104× 4,128画素，385dpiの高解像度なLTPS (低温ポリシリコン) 背面板の試作物が展示された. 特筆すべきは, 白黒二值表 示ながら，初期のレーザプリンタを上回る解像度を活用し て, 誤差拡散法などの面積階調表現を実現している点であ る。これは複雑な駆動波形なしに，実質的なグレースケー ル表示を, 白黒二值ゆえの高速な画面更新で実現できるこ とを意味する。

\section{3 カラー化}

反射型の電子ペーパのカラー化には, カラーフィルタを 用いる方法や，コレステリック液晶のようにRGBの三層を 積層構造にする方法 ${ }^{22)}$ などがある。2005年の F P D International展では, 筆者のグループで共同開発した6イン チ，400×300画素，4,096色表示の試作品を展示した．これ はカラーフィルタの赤・緑・青のサブ画素に加え, 白のサ ブ画素を設けることで，白状態の反射率を従来の約 $16 \%$ か

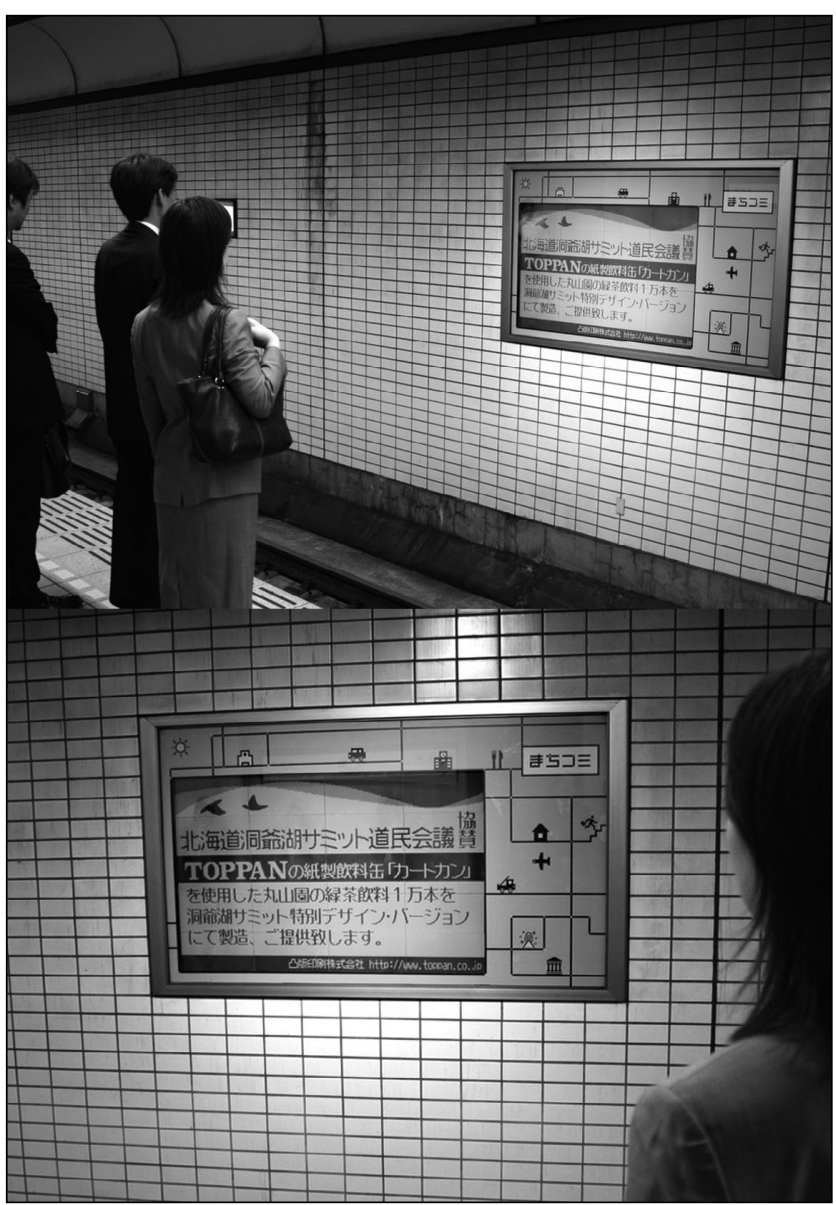

図8 地下鉄仙台駅の電子ペーパサイネージ(口絵カラー参照)

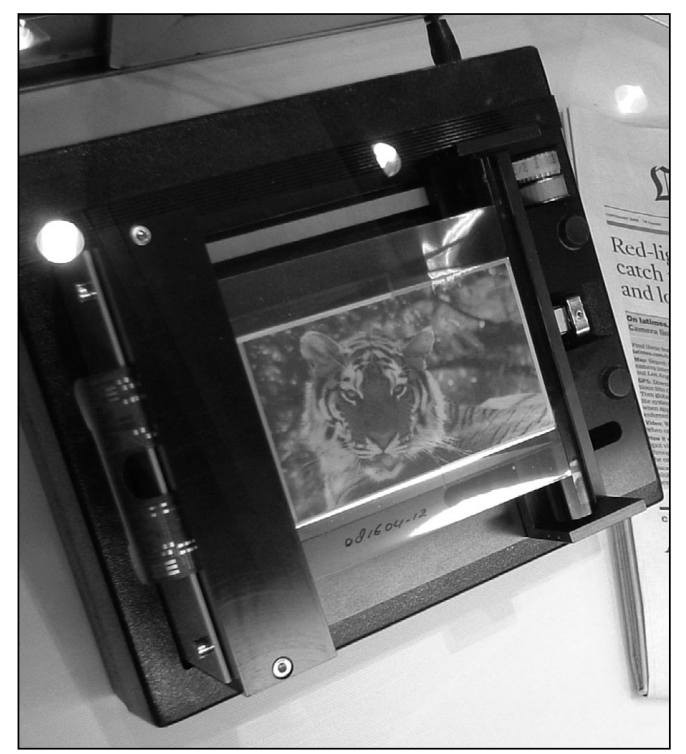

図9 フレキシブルカラ一電子ペーハロ絵カラー参照)

ら約 $22 \%$ に改善した。

2008年後半は，世界初のフレキシブル電子ペーパディス プレイ ${ }^{23)}$ 採用商品 ${ }^{24)}$ が発売予定であるが，2008年のSIDで は，その次として，フレキシブルなカラー電子ペーパ(図9) を, カラー印刷された新聞の横に展示して, 完成度の高さ

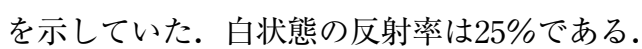


表示材料にしきい值特性がないため, 電気泳動方式の高 精細型電子ペーパディスプレイはTFT駆動するのが一般的 であるが，市販品は，グレースケール表示において画面更 新に 1 秒弱掛かる。 パッシブ駆動可能な他方式の更新は線 順次であるためさらに遅く, 電子ペーパ全般の欠点と言わ れている。このため読書のように，ページを切替える用途 に限定され，ユーザインタフェースに用いるのが困難であ る. 先述の無線通信型電子ブックリーダーは, 電子ペーパ の主画面の右に, 高速応答が可能なポリマーネットワーク 液晶による縦長のスクロールバーを設けて打り，スクロー ルホイールを回してクリックすることでメニュー選択を行 い，主画面の表示更新の遅さを補う工夫がされている.

2008年春に, 電気泳動方式専用の高速な電子ペーパコン トローラ $\mathrm{IC}^{25)}$ が開発された。これは異なる駆動波形を割当 可能な, 部分書換え可能なパイプラインを独立に16個持つ ことで，高速な描画・更新を実現し，電子ペーパでユーザ インタフェース操作を可能にしている．このコントローラ ICは量産が開始されており ${ }^{26)}$, 電磁誘導式のペンタブレッ トと組合せた評価キット ${ }^{27)}$ を購入することも可能である. 高速化が，電子ペーパのさらなる普及につながると期待さ れている.

\section{6 今後の展望}

以上，既存の印刷技術について概説するとともに，有機卜 ランジスタへの適用例，そして電子ペーパ関連の最近の動 向を紹介した，印刷技術によるデイスプレイ製造は，従来 の真空プロセスやフォトリソグラフィと異なり, 高価な装 置や複雑な工程が不要であり, 材料の利用効率も高く, 製 造コストを劇的に下げる生産技術として期待されている27).

印刷技術そのものは古いものであるが，そのディスプレ イ製造への適用はまだ始まったばかりである。現状の印刷 技術の多くは，情報伝達の手段として特化しており，これ をディスプレイ製造へ適用するためにはそれに適合させる ための技術開発が求められる.

また，材料面についても機能だけを求めるだけでなく， 印刷プロセスに適した材料設計がされることが望ましい. 同様にデバイス設計においても，それら両者の特性を最大 に引き出せるような検討が必要である.このためには材料, 設計，プロセスのそれぞれの研究者，技術者の密接な協力 体制を構築し, 議論していくことが必要である.

パーソナルコンピュータとインターネット時代の今も， 紙と印刷は身近な存在であるが，遠から近い将来の，真 のユビキタスコンピューティング28) 時代には，印刷技術を 活用して製造された電子ペーパなどの情報ディスプレイ が，静かにわれわれの生活を支援することを期待したい．

最後に，本稿の執筆にあたりご協力いただいた，凸版印 刷技術戦略部の中村隆一氏に深く感謝します。

\section{〔文 献〕}

1）今井拓司ほか：“インビジブル・エレクトロニクス”, 日経エレクト ロニクス，2005年5月23日号，pp.97-133（2005）

2）檀上英利：日本化学会第85春季年会ATP，3L5-24（2005）

3）角田ほか：“基本印刷技術”, 産業図書（1978）

4) H. Sirringhaus et al.: "34.1: Active Matrix Displays Made with Printed Polymer Thin Film Transistors", SID 03 Digest, pp.1084-1087 (2003)

5) G. Gelinck et al.: "Flexible Active-matrix Displays and Shift Registers Based on Solution-processed Organic Transistors", Nature Materials, 3. Feb.2004, pp.106-110 (2004)

6) M. Ito et al.: "A Flexible Active-matrix TFT Array with Amorphous Oxide Semiconductors for Electronic Paper", IDW/AD '05 Proceedings, 1, pp.845-846 (2005)

7）Amazon, Kindle製品紹介, http://www.amazon.com/kindle/

8）Sony，リブリエ製品紹介，http://www.sony.jp/products/Consumer/ LIBRIE/

9）Sony社Reader製品紹介，http://www.sony.com/reader/

10) Amazon, 2007 Letter to Shareholders, http://www.secinfo.com/ d14D5a.t2Y5u.d.htm\#1stPage

11) Motorola，MOTOFONE製品紹介，http://direct.motorola.com/ hellomoto/motofone/

12)KDDI，W61H製品紹介，http://www.au.kddi.com/seihin/ichiran/ cdmalx_win/w61h/

13)「G'zOne W62CA」開発者インタビュー, http://k-tai.impress.co.jp/ cda/article/interview/40390.html

14)KDDI，W62CA製品紹介，http://www.au.kddi.com/seihin/ichiran/ cdmalx_win/w62ca/

15)PVI，EPD製品仕様紹介，http://www.pvi.com.tw/en/products/ p065.php

16) ブリデストン，応用製品開発キット紹介，http://www2.bridgestonedp.jp/adv-materials/QR-LPD/development.html

17)EETimes SID 2007関連記事, http://www.eetimes.jp/contents/ 200705/19045_1_20070523151449.cfm

18)凸版印刷，ニュースリリース，http://www.toppan.co.jp/news/ newsrelease645.html

19) 凸版印刷，ニュースリリース，http://www.toppan.co.jp/news/ newsrelease $774 . h t m l$

20)凸版印刷，ニュースリリース，http://www.toppan.co.jp/news/ article0113.html

21)EPSON，ニュースリリース, http://www.epson.jp/osirase/ 2006/060612.htm

22) 富士通研究所，電子ペーパ構造紹介，http://jp.fujitsu.com/group/ labs/techinfo/techguide/list/paper_p03.html

23)E. Huitema et al.: "60.4: Invited Paper: Rollable Displays - A Technology Development Enabling Breakthrough Mobile Devices", SID 08 Digest, pp.927-930 (2008)

24) Polymer Vision，Readius製品紹介，http://www.polymervision.com/ site/page/19/20/Readius\%AE/

25) H. Gates et al.: "46.3: High Performance Active Matrix Electro phoretic Display Controller", SID 08 Digest (2008), pp.693-696

26) EPSON, ニュースリリース, http://www.epson.jp/osirase/2008/ 080416.htm

27)E Ink, AM300 Prototype Kit紹介, http://eink.com/kits/ amepd.html

28) M. Weiser: "Ubiquitous Computing", http://www.ubiq.com/ubicomp/

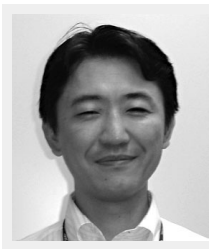

韻上英英利 1989年, 京都大学大学院情報工学研 究科修了．同年，凸版印刷 (株) 入社. システム開発等 に従事. 1993年，米国駐在．インターネット関連活動 を行い，1997年，MIT客員研究員資格取得．2000年， USC経営学修士取得. 2001年に帰国後, 電子ペーパの 事業化を推進. 